\title{
UMBATRA
}

Indonesian Journal of Anthropology

Volume 4 (1) Juli 2019 || eISSN 2528-1569 | pISSN 2528-2115 || http://jurnal.unpad.ac.id/umbara

DOI : $10.24198 /$ umbara.v4i1.21441

\section{Pengembangan Geowisata dan Perubahan Sosial-Budaya Masyarakat di Area Geopark Ciletuh-Palabuhanratu}

\author{
Syafira Ayudarechta Tara Wendita \\ Pusat Perencanaan dan Pengembangan Kepariwisataan, Institut Teknologi Bandung \\ ayudarechta@gmail.com
}

\begin{abstract}
Ciletuh-Palabuhanratu Geopark has been inaugurated as the first global geopark in the West Java Province in April 2018. Since 2002, geotourism is the development model being chosen by the geopark management to popularize this geopark. This study aims at describing the influence of geotourism development on socio-cultural changes in people who live in the Ciletuh-Palabuhanratu Geopark. This study uses qualitative methods in particular case study. Primary data collection include in-depth interviews and participant observation and secondary data was collected through archival studies. This study finds indications the socio-cultural changes of the communities living at the geopark area along with the development of geotourism. There is a change in the livelihoods form among the community members from peasant and fishermen to tourism businessmen. There is also a growing of local organizations working on tourism management, revitalization of local traditional arts for tourism commodities, and the emergence of new patterns of social interaction between local communities and tourists.
\end{abstract}

Keywords: Geopark, Geotourism, Change, Commodification

\begin{abstract}
Abstrak
Geopark Ciletuh-Palabuhanratu diresmikan sebagai geopark global pertama di Provinsi Jawa Barat pada April 2018. Sejak pertama kali dirintis pada 2002 hingga saat ini, geowisata merupakan model pengembangan yang dipilih untuk mempopulerkan geopark ini pada khalayak ramai. Penelitian ini bertujuan menggambarkan pengaruh pengembangan geowisata pada perubahan sosial-budaya masyarakat yang tinggal di lokasi Geopark Ciletuh-Palabuhanratu. Penelitian ini menggunakan metode kualitatif dengan model studi kasus. Data primer dikumpulkan dengan cara wawancara mendalam dan pengamatan terlibat. Data sekunder dikumpulkan melalui studi arsip. Penelitian ini menemukan beberapa jenis perubahan yang menandakan adanya perubahan sosial-budaya pada masyarakat di geopark ini, yang muncul seiring dengan pengembangan geowisata; yaitu perubahan mata pencaharian, dari petani, peternak, dan nelayan menjadi pelaku usaha wisata, tumbuhnya organisasi lokal untuk pengelolaan pariwisata, revitalisasi seni tradisi lokal sebagai komoditi wisata, dan munculnya pola interaksi sosial baru antara masyarakat lokal dengan para wisatawan.
\end{abstract}

Kata kunci : Geopark, Geowisata, Perubahan Sosial-budaya, Komodifikasi 


\section{Pendahuluan}

Situs geologis (geosite) adalah sebuah area dengan keunikan geologis yang biasanya berumur ratusan tahun. Saat ini terdapat seki$\operatorname{tar} 40$ situs warisan geologi di Indonesia. Empat situs telah menjadi geopark internasional, atau dikenal dengan istilah geopark global, yaitu Gunung Rinjani di Provinsi Nusa Tenggara Barat, Danau Batur di Provinsi Bali, Gunung Sewu di Provinsi Daerah Istimewa Yogyakarta, dan Ciletuh-Palabuhanratu di Provinsi Jawa Barat.

Geopark Ciletuh-Palabuhanratu terletak di Kabupaten Sukabumi, sekitar 211 kilometer timur Jakarta, dan dapat ditempuh dalam waktu \pm 6 Jam melalui rute Jakarta - Sukabumi Kota - Kecamatan Ciemas. Wilayah geopark ini mencakup delapan kecamatan yaitu Ciemas, Cisolok, Cikakak, Palabuhanratu, Simpenan, Waluran, Ciracap, dan Surade. Kedelapan kecamatan itu berada dalam tiga wilayah geologis dengan karakter dan tema berbeda.

Wilayah pertama adalah geoarea Ciletuh dengan karakter dan tema fosil subduksi, mencakup Kecamatan Ciemas, Ciracap, Surade dan Waluran. Titik pusat zona ini adalah tebing Panenjoan yang terletak di Desa Tamanjaya. Kecamatan Ciemas. Tebing ini merupakan bentang alam raksasa yang berbentuk amfiteater dengan panjang 12 kilometer dan lebar 7 kilometer. Wilayah kedua adalah geoarea Simpenan dengan tema bentang alam plato Jampang, yang berada di Kecamatan Waluran. Wilayah geoarea ketiga dengan tema pergeseran jalur magmatik, mencakup wilayah Kecamatan Cisolok, Cikakak dan Palabuhanratu.

Selain merupakan kawasan dengan keragaman geologis, Ciletuh-Palabuhanratu juga merupakan kawasan dengan keragaman hayati. Pada kawasan hutan negara seluas 8.574,50 hektar, di dalamnya terdapat kawasan suaka margasatwa Cikepuh seluas 8.127,50 ha dan kawasan cagar alam Cibanteng seluas 447 hektar. Wilayah hutan negara ini menyimpan kekayaan dan keragaman hayati berupa flora dan fauna endemik Jawa Barat yang terancam punah; seperti banteng, kera owa, burung udang, burung merak, dan bunga Raflesia Padma (Badan Pengelola Geopark Ciletuh Palabuhanratu, 2015).

Keragaman budaya juga menjadi kekayaan wilayah Ciletuh-Palabuhanratu. Beberapa warisan budaya yang masih ditemukan adalah kesenian, di antaranya berupa seni musik dan pertunjukan, tradisi lisan berupa cerita rakyat, sistem organisasi sosial berupa struktur organisasi masyarakat pedesaan, sistem teknologi pertanian (tatanen) lahan kering, dan sistem religi yang merupakan campuran antara Islam dan kepercayaan lokal. Kekayaan dan keragaman budaya itu disinyalir mulai tumbuh seiring dengan sejarah geologis di wilayah tersebut (Rosana, 2016).

Geopark Ciletuh-Palabuhanratu saat ini menjadi satu-satunya geopark global di Provinsi Jawa Barat. Pengembangan wilayah ini sebagai situs geologi telah dimulai sejak 2002, saat pemerintah setempat mulai mengenali potensi geologi wilayah ini untuk pertama kali. Puncak pengembangannya dimulai sejak April 2018, saat geopark ini resmi diakui sebagai geopark global oleh lembaga geopark UNESCO. Status baru sebagai geopark global mendorong Badan Pengelola Geopark menjadi lebih intensif memperkenalkannya pada khalayak umum; salah satunya melalui geowisata. Jenis kegiatan geowisata yang telah disiapkan oleh pengelola adalah: Geosite sightseeing (berkeliling melihat-lihat situs geologi), Geo-tours (tur geologis), Geo-sport (wahana olah raga di aera geopark), Geo-study (wahana pendidikan di area geopark), Geo-conservation (wahana pelestarian alam di area geopark) dan Geo-festival. Kegiatan tersebut ditunjang oleh tersedianya jalur geowisata yang dapat digunakan untuk mengenal aneka bentukan geologi, yaitu: batuan tua, geomorfologi, fosil, gua laut, batuan bentukan unik, air terjun, dan struktur sedimen. 
Badan Pengelola Geopark Ciletuh-Palabuhanratu (BPGCP) juga telah membangun tujuh jalur geowisata yang telah disesuaikan dengan berbagai jenis daya tarik wisata geologi, keanekaragaman hayati serta budaya yaitu; Jalur Geowisata 1 (Menyusuri Curug, Surganya Pajampangan); Jalur Geowisata 2, (Mendaki puncak tertinggi di Desa Girimukti); Jalur Geowisata 3 (Menyaksikan gemerlap bebatuan di Desa Mandrajaya); Jalur Geowisata 4 (menyaksikan Jejak Fosil Tektonik di Ciletuh); Jalur Geowisata 5 (melihat hamparan bebatuan ter-hadé (terbaik) di Surade); Jalur Geowisata 6 (menyaksikan sejarah tektonik di Jawa Bagian Barat; dan Jalur Geowisata 7 (menyaksikan jejak tumbukan lempeng Hindia-Australia dengan Eurasia Sejak Zaman Kapur (BPGCP, 2017).

Penangkaran penyu dan wisata greenbelt (sabuk hijau) di kawasan hutan bakau di Pantai Pangumbahan adalah salah satu komoditas geowisata yang menyajikan keanekaragaman hayati yang ditawarkan pada para wisatawan. Selain itu, pengembangan kuliner tradisional berupa roti berbentuk penyu, industri batik motif Pakidulan, dan pengembangan seni pertunjukan lokal berupa tari-tarian adalah sebagian dari keragaman budaya yang dikembangkan menjadi komoditas geowisata.

Aneka perbaikan fasilitas dilakukan untuk menunjang geowisata, seperti perbaikan jalan menuju area geopark, pembentukan jasa perjalanan wisata menuju geopark, pembukaan penginapan dan warung untuk melayani pengunjung, bahkan festival geopark. Arus kunjungan wisatawan ke wilayah ini pun mulai meningkat sejak promosi gencar geowisata dilakukan, baik oleh pemerintah setempat maupun oleh para wisatawan yang pernah berkunjung. Kedatangan wisatawan ke lokasi geopark diikuti oleh peningkatan kegiatan transaksi, baik transaksi ekonomi, maupun transaksi sosial-budaya yang terjadi melalui interaksi antara warga setempat dengan para

\footnotetext{
${ }^{1}$ Istilah geopark lebih banyak digunakan dalam penyebutan taman bumi di Indonesia. Contohnya dalam nama resmi Geopark Ciletuh Palabuhanratu di Kabupaten Sukabumi dan Geopark Merangin di Jambi.
}

Konsep geopark di Indonesia mengusung pengembangan wilayah secara keberlanjutan dengan menggabungkan ketiga keragaman yaitu keragaman geologi, keragaman hayati dan keragaman budaya (Yuliawati, et al, 2016). Pengembangan keberlanjutan erat kaitannya dengan pengembangan masyarakat. Sebuah pengembangan masyarakat dapat menjadi proses dalam pemberdayaan, ditandai dengan masyarakat mandiri dalam berpikir, bersikap wisatawan. Kondisi sosial-budaya pun menja-
di lebih dinamis akibat interaksi tersebut. Perubahan-perubahan dalam kehidupan keseharian masyarakat di area geopark mulai terlihat, seperti perubahan bentuk mata pencaharian, to hingga revitalisasi seni tradisi yang hampir punah. Penelitian ini bertujuan menelusuri dan menggambarkan pengaruh pengembangan geowisata di Geopark Ciletuh-Palabuhanratu pada kondisi sosial dan budaya masyarakat di dua kecamatan yaitu Kecamatan Ciemas dan Kecamatan Ciracap yang terletak di area geopark tersebut.

Beberapa situs geologi di dunia dilestarikan melalui sebuah sistem manajemen pengembangan yang disebut geopark atau taman bumi ${ }^{1}$. Geopark tidak hanya mencakup sistem manajemen konservasi warisan geologi semata tetapi juga sistem manajemen pembangunan berkelanjutan yang bertujuan meningkatkan kesejahteraan masyarakat yang tinggal di area situs geologi tersebut (Keever dan Zouros, 2005). Pengembangan geopark internasional, mencakup tiga aspek konservasi dan pengembangan yaitu keragaman geologi, biologi, dan budaya. Pengembangan geopark di Indonesia mengikuti prinsip tersebut dan menjadi salah satu wujud paradigma baru pembangunan berkelanjutan dalam pengelolaan sumberdaya alam (Yuliawati, et al, 2016). 
dan mengambil keputusan dan sudah mampu berorientasi jangka panjang, makro dan subtansial sebagai tanda terberdayakannya masyarakat serta realisasi pengembangan masyarakat tersebut (Zubaedi, 2013).

Geowisata merupakan bentuk kegiatan pariwisata yang fokus utamanya pada tampilan geologis permukaan bumi maupun yang terkandung didalamnya. Geowisata bertujuan mendorong pemahaman pada lingkungan hidup, alam dan budaya, sebagai bentuk apresiasi sekaligus kegiatan konservasi alam, serta memupuk kepedulian terhadap kelestarian kearifan lokal (Ginting dan Sasmita, 2018; Wood, 2002; dan Chen, Lu, dan Ng, 2015).

Proses-proses pengembangan geowisata dapat memacu timbulnya perubahan-perubahan sosial-budaya di masyarakat. Soekanto (2012) mendefinisikan perubahan sosial sebagai segala perubahan pada lembaga-lembaga kemasyarakatan di dalam suatu masyarakat, yang memengaruhi sistem sosialnya, di dalamnya termasuk nilai-nilai, sikap-sikap, dan pola-pola perilaku di antara kelompok-kelompok dalam masyarakat. Kingsley Davis dalam Soekanto (2012) berpendapat bahwa perubahan sosial merupakan bagian dari perubahan kebudayaan yang mencakup: kesenian, ilmu pengetahuan, teknologi, filsafat bahkan perubahan dalam organisasi sosial. Perubahan kebudayaan merupakan suatu proses adaptasi atau seleksi alam. Dilihat dari sistem adaptif, budaya berubah ke arah keseimbangan ekosistem. Namun, apabila perubahan yang diinginkan tersebut tidak sesuai dengan apa yang diinginkan maka akan terjadi ketidakseimbangan karena terganggu oleh perubahan lingkungan, teknologi, atau gangguan dari faktor lain yang datang dari dalam maupun dari luar kelompok manusia tersebut (Keesing, 1997). Perubahan sosial dan budaya dapat dibedakan menjadi beberapa bentuk, yaitu: 1) Perubahan lambat dan cepat; 2) Perubahan kecil dan perubahan besar; 3) Perubahan yang dikehendaki (Intended-change) atau perubahan yang direncanakan (Planned-change) dan perubahan yang tidak dikehendaki (Unintended-change) atau perubahan yang tidak direncanakan (Unplanned-change) (Soekanto, 2012).

Pariwisata secara langsung menyentuh dan melibatkan masyarakat, sehingga membawa berbagai perubahan terhadap masyarakat setempat (Wahyudi, 2012). Penelitian Biantoro dan Mar'rif (2014) menjelaskan, terjadi perubahan pada nilai sosial dan budaya masyarakat, yang di ukur melaui intensitas masyarakat dalam mengikuti kegiatan sosial diketahui bahwa masyarakat yang bekerja di dalam sektor pariwisata menyatakan, semenjak bekerja di dalam sektor pariwisata Candi Borobudur mereka jarang atau kadang -kadang dalam mengikuti kegiatan sosial yang ada di lingkungan mereka (Biantoro dan Ma'rif, 2014). Perubahan serupa muncul dari adanya pariwisata terhadap alih fungsi lahan di Desa Tibubeneng memicu masalah-masalah sosial seperti meningkatnya kriminalitas, juga hilangnya budaya menghaturkan persembahan menghilangakan nilai kesakralan ritual keagamaan desa adat dan tumbuhnya sifat individualis yang berpandangan profit oriented (Dipayana dan Sunatra, 2015).

Perubahan sosial-budaya mencakup unsur-unsur kebudayaan baik yang bersifat materiil maupun yang immaterial dengan menekankan pengaruh yang besar dari unsur-unsur kebudayaan yang materiil terhadap unsur-unsur immaterial (William F. Ogburn dalam Lauer, 1993). Proses perubahan sosial dan budaya ditandai dengan proses belajar unsur-unsur kebudayaan asing oleh warga masyarakat. Bentuk perubahan kebudayaan dapat berupa akulturasi (acculturation), asimilasi (assimilation), inovasi (innovation), penemuan baru (discovery dan invention) (Koentjaraningrat, 1997).

Masyarakat merupakan sistem adaptif, dan budaya masyarakat pun berubah untuk tujuan adaptasi pada keseimbangan ekosistem. Apabila perubahan budaya tersebut tidak sesuai dengan ekosistem tempat masyarakat 
tinggal, maka akan terjadi ketidakseimbangan (Keesing, 1997).

Perubahan dan diversifikasi mata pencaharian merupakan salah satu indikasi perubahan sosial-budaya di masyarakat. Perubahan mata pencaharian merupakan proses struktural di mana sumber lapangan kerja dan pendapatan penduduk desa dikembangkan dan diperluas (Scoones, 2015). Selain perubahan bentuk mata pencaharian, gejala komodifikasi juga merupakan salah satu bukti perubahan sosial-budaya.

Kegiatan pariwisata seringkali memicu terjadinya komodifikasi budaya. Konsep komodifikasi merujuk pada upaya penggunaan bagian tubuh manusia hingga budaya yang dimiliki masyarakat untuk direduksi menjadi bahan baku produk yang dapat dijual (Sharp, 2000; Shepherd, 2002 dalam (Febriyanto, Riawanti, dan Gunawan, 2017)). Di dalam konteks pariwisata, konsep komodifikasi budaya merujuk pada upaya pemanfaatan kekhasan budaya, untuk menjadi komoditas pariwisata. Pembentukan identitas baru masyarakat terjadi dengan adanya komodifikasi budaya sebagai komoditas pariwisata yang mendorong adanya kapitalisasi budaya seperti yang terjadi pada anak rambut gimbal di Dieng (Febriyanto, Riawanti, dan Gunawan, 2017). Hal tersebut dilakukan secara sadar dan direncanakan, karena tujuan utamanya untuk konsumsi wisatawan tanpa menghiraukan kualitas yang seharusnya dipelihara (Yoety, 1994). Banyak penelitian menemukan bagaimana kerajinan, kinerja, fotografi, perhotelan dan identitas telah diubah oleh kehadiran wisatawan (Cole, 2008). Hal ini pada akhirnya menurunkan kualitas komoditas dan juga otentisitasnya.

\section{Metode}

Penelitian ini dilakukan dengan menggunakan disain penelitian kualitatif model studi kasus. Kasus dalam penelitian ini merujuk pada fenomena di dalam konteks kehidupan nyata yaitu kehidupan masyarakat di lokasi geopark dengan segala perubahan sosial budayanya yang terjadi seiring dengan pengembangan geopark. Data primer dalam penelitian ini diperoleh melalui wawancara mendalam dan partisipasi observasi. Data sekunder dikumpulkan melalui studi arsip.

Pemilihan infoman dilakukan dengan prinsip purposive sampling (Creswell, 2016). Jumlah informan penelitian adalah 12 orang dengan latar belakang yang beragam. Sebanyak enam informan adalah warga masyarakat yang memutuskan beralih mata pencaharian, empat informan adalah para aktivis di komunitas setempat yang bergerak di bidang konservasi dan pegiat budaya; dan dua informan lainnya adalah masyarakat kreatif yang berupa menciptakan lapangan pekerjaan baru di wilayah tempat tinggalnya.

\section{Hasil dan Pembahasan}

\section{Profil Kecamatan Ciemas dan Ciracap}

Kecamatan Ciemas dan Ciracap adalah dua kecamatan yang pertama kali menjadi kawasan geopark di Ciletuh. Gerbang Geopark yaitu Tebing Panenjoan, rumah Batik Pakidulan, Konservasi Penyu dan acara "Ciletuh-Palabuhanratu Geopark Festival" diadakan di kedua kecamatan tersebut.

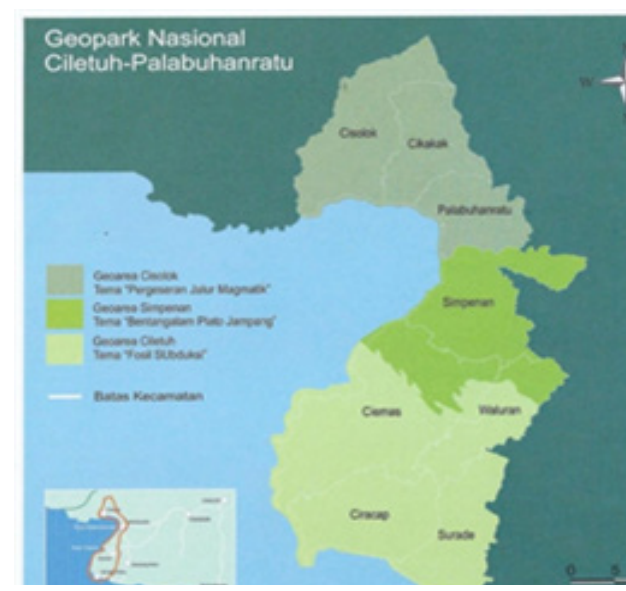

Gambar 1. Peta Kawasan Geopark Nasional Ciletuh Sukabumi, Jawa Barat (Andriany, Rosana, \& Hardiyono, 2016)

Kecamatan Ciemas berbatasan dengan Kecamatan Simpenan di bagian utara, dan bagian 
timur berbatasan dengan Kecamatan Ciracap. Sementara di bagian selatan dan barat berbatasan dengan Samudra Hindia. Wilayah Kecamatan Ciemas memiliki luas 26.316 ha, terdiri dari lahan pertanian seluas 17.008 ha, sawah 4.184 ha, tanah kering 12.824 ha, pekarangan 3.963 ha dan hutan negara 9.197 ha. Kecamatan Ciemas terletak pada ketinggian 10-400 meter di atas permukaan laut dengan jarak dari ibu kota Kabupaten adalah $61 \mathrm{~km}$. Jarak Kecamatan Ciemas dari ibu kota provinsi sekitar $214 \mathrm{~km}$ sedangkan dari ibu kota negara yaitu sekitar $223 \mathrm{~km}$. Jumlah penduduk Kecamatan Ciemas adalah 54.288 jiwa, dengan jumlah penduduk laki-laki sebanyak 27.327 jiwa dan perempuan sebanyak 26.961 jiwa. Rata-rata kepadatan adalah 166 jiwa/ 100 ha (Kecamatan Ciemas dalam Angka tahun 2015).

Wilayah kecamatan Ciracap sebagian besar berada pada kawasan pegunungan dan hutan. Kecamatan ini berbatasan dengan Kecamatan Waluran di sebelah Utara, Samudera Indonesia di sebelah Selatan, Kecamatan Surade di sebelah Timur dan Kecamatan Ciemas di sebelah Barat. Kecamatan Ciracap terletak 75 km dari ibu kota kabupaten (Sukabumi), 216 $\mathrm{km}$ dari ibu kota provinsi (Bandung) dan 233 $\mathrm{km}$ dari ibu kota negara (Jakarta).

Kecamatan Ciracap memiliki luas wilayah 16.802 ha. Luas tersebut meliputi areal pesawahan seluas $4.379,7$ ha, luas hutan negara seluas 420 ha dan luas perkebunan serta pemukiman seluas 12.002,3 ha. Wilayah Kecamatan Ciracap ini sebagian besar terletak di daerah dataran dan lereng/ punggung bukit. Jumlah Penduduk Kecamatan Ciracap adalah 51.068 jiwa, dengan jumlah penduduk laki-laki sebanyak 25.333 jiwa dan perempuan sebanyak 25.735 jiwa. Rata-rata kepadatan penduduknya adalah 312 jiwa/ 100ha. (Kecamatan Ciracap dalam Angka tahun 2015).

\section{Diversifikasi Mata Pencaharian dan Pelu- ang Usaha Baru}

Pada mulanya masyarakat di Kecamatan Ciracap dan Kecamatan Ciemas berprofesi sebagai petani, nelayan, penambang dan pedagang. Di antara profesi ini, penambang adalah profesi terbanyak. Di beberapa wilayah yang saat ini telah menjadi wilayah geopark terdapat areal penambangan rakyat, dengan komoditi seperti pasir besi, pasir kuarsa dan batu gamping.

Salah satu bagian dari upaya pengembangan Geopark Ciletuh-Palabuhanratu adalah konservasi yang bertujuan menjaga keaslian dan kelestarian situs geopark. Pantai Karang Bolong, adalah salah satu tempat yang menjadi areal penambangan rakyat. Bahan yang ditambang adalah pasir besi. Saat pengembangan geopark dimulai, aktivitas penambangan rakyat dikategorikan ilegal dan dilarang.

Pak Arif (48 tahun), salah seorang tokoh masyarakat di Desa Mandrajaya, Kecamatan Ciemas bercerita, areal penambangan emas yang terdapat di Kecamatan Ciemas bermula karena adanya orang-orang luar daerah yang mencari lahan penambangan baru yang dianggap potensial di kecamatan ini. Lahan penambangan dibuka di lahan hasil pembebasan lahan warga. Penambangan tersebut mempekerjakan beberapa warga masyarakat, sehingga penambangan tersebut dapat beroperasi secara baik karena dianggap membantu ekonomi masyarakat. Meskipun perizinannya sudah ada dari tingkat kabupaten, tetapi menurut Arif, pihak pengembang geopark mengatakan bahwa kegiatan penambangan dianggap tidak sejalan dengan prinsip geopark. Aktivitas penambangan yang berupa pembukaan lahan dan pengambilan bahan tambang dari dalam tanah dianggap membahayakan keaslian dan kelestarian situs.

Otoritas pengembangan geopark, Badan Pengelola Geopark, berupaya membebaskan wilayah geopark dari aktivitas penambangan. Upaya pembebasan ini dilakukan bertahap, dimulai dengan sosialisasi yang bertujuan memperkenalkan geopark kepada masyarakat. Sosialisasi berupa pemahaman mengenai geopark serta pelatihan-pelatihan pemandu 
wisata dan homestay ${ }^{2}$ pada masyarakat disampaikan oleh Badan Pengelola Geopark. Menurut Arif sosialisasi dan pelatihan dalam jangka waktu satu sampai dua tahun secara berkala agar masyarakat dapat mengerti manfaat dari konservasi tersebut. Selain itu upaya penertiban aktivitas penambangan di situs-situs geologis juga dilakukan dengan cara menerbitkan larangan tertulis dan memberlakukan denda terhadap penambangan yang dilakukan pada situs geologis.

Pembatasan dan pelarangan penambangan oleh pengelola geopark membuat masyarakat yang semula bermata pencaharian sebagai penambang ilegal (tidak berizin dari pemerintah) terpaksa beralih mata pencaharian. Para penambang ilegal di situs geologis Karang Bolong merupakan salah satu kelompok yang beralih mata pencaharian.

Hadi (39) adalah salah satu warga masyarakat di Karang Bolong yang dulunya menjadi penambang. Pada awalnya ia kecewa dengan pelarangan penambangan karena hal itu sudah menjadi kegiatannya selain menjadi petani kebun. Namun, setelah mengetahui sebab pelarangan penambangan, ia baru menyadari rusaknya pasir yang ada di Karang Bolong akibat pencemaran penambangan. Hadi dan sejumlah masyarakat lainnya yang semula menjadi penambang mendapat pelatihan untuk penghijauan kembali kawasan pertambangan serta mendapatkan pelatihan untuk mengasah keterampilan lain. Masyarakat yang pada awalnya menjadi penambang ilegal, saat ini telah berubah mata pencaharian menjadi pemandu wisata untuk program adopsi pohon dalam kegiatan greenbelt di situs geologis Karang Bolong.

Selain di Karang Bolong, program adopsi pohon juga dapat ditemukan dalam kegiatan konservasi terumbu karang di sepanjang Pantai Pangumbahan. Kegiatan konservasi tersebut dilakukan oleh Kelompok Masyarakat Konservasi (Pokmasi) dan Kelompok Mas- yarakat Pengawas (Pokmaswas) yang didirikan oleh Dinas Perikanan dan Kelautan Kabupaten Sukabumi. Namun, sebagian besar anggota kelompok tersebut adalah warga Kecamatan Ciracap yang bermata pencaharian sebagai nelayan di Pantai Ujunggenteng dan Pangumbahan yang peduli terhadap lingkungan di Kecamatan Ciracap.

Selain Hadi, Tanto (51) juga beralih profesi dari penambang menjadi pelaku pariwisata. Ia bergabung dengan Discover Jampang bersama dengan Pokmasi. Ia kini menjadi seorang aktivis komunitas berbasis masyarakat yang aktif dalam program Green Camp dan greenbelt di situs geologis Karang Bolong. Ia menuturkan tentang perubahan mata pencaharian warga termasuk dirinya pasca dilarangnya aktivitas penambangan. Green Camp dan greenbelt adalah salah satu kegiatan konservasi yang dilakukan di situs geologis Karang Bolong sebagai upaya penghijauan setelah dilarangnya aktivitas penambangan,

Sapri (48), salah satu nelayan dan juga anggota dari Pokmaswas, mengungkapkan bahwa ia dan nelayan lainnya bergabung dalam Pokmasi dan Pokmaswas karena mata pencaharian mereka tergantung pada laut, tetapi sejak ada pengembangan geopark, ada pembatasan bagi mereka dalam mencari nafkah di laut serta anjuran bagi nelayan untuk mencegah kerusakan laut. Sapri juga bercerita bahwa konservasi terumbu karang yang dilakukan pada awalnya bersifat murni karena konservasi yang dilakukan oleh Pokmasi dan Pokmaswas. Namun, seiring waktu, semakin banyak wisatawan yang ingin melihat proses penanaman terumbu karang. Akhirnya kegiatan tersebut diubah oleh Pokmasi dan Pokmaswas menjadi program wisata adopsi terumbu karang.

Komunitas lokal seperti PAPSi bekerjasama dengan Himpunan Pramuwisata Indonesia (HPI) dan Persatuan Hotel dan Restoran Indonesia (PHRI) memfasilitasi pembinaan bagi warga masyarakat yang ingin menjadi peman-

${ }^{2}$ Istilah homestay (untuk menyebutkan rumah penginapan) lebih umum digunakan di Geopark Ciletuh Palabuhanratu 
du wisata dan bagi warga yang ingin membuka usaha homestay. Sampai tahun 2017, sebagai hasil dari pembinaan telah muncul lima pemandu lokal bersertifikat dan 40 homestay di kawasan Geopark Ciletuh-Palabuhanratu (disebut geohomestay) khususnya di area Ciracap dan Ciemas.

Kakan (32), adalah salah satu pemandu lokal yang belum bersertifikat. Namun, ia telah beberapa kali mendapat tawaran untuk mendampingi wisatawan ke sejumlah situs geologis yang ada di geopark. Latar belakang pendidikan Kakan adalah SMA, tetapi terpaksa putus sekolah karena harus bekerja. Ia menjelaskan, bahwa saat ini ia masih dalam tahap belajar untuk mendapat sertifikat khusus sebagai pemandu wisata di Geopark Ciletuh-Palabuhanratu. Menurutnya, semakin ramainya tempat tinggalnya saat ini akan sangat menguntungkan dirinya apabila ia berkecimpung di jasa pariwisata untuk mencari penghasilan.

Homestay adalah sebuah konsep baru yang diperkenalkan oleh PAPSi pada masyarakat. Salah satu anggota PAPSi, Erlan (48), menjelaskan bahwa homestay adalah rumah singgah yang disewa oleh wisatawan yang ingin tinggal sementara dengan warga. Pemilik rumah atau host family hidup bersama wisatawan penyewa homestay selama beberapa hari dan saling berinteraksi langsung dengan tujuan agar wisatawan lebih mengenal bahasa, budaya, keseharian dan kearifan lokal dari masyarakat setempat. Erlan bercerita, homestay kini menjadi salah satu sumber penghasilan baru bagi warga di Desa Tamanjaya, Kecamatan Ciemas. Namun, hanya beberapa pemilik homestay yang mengetahui bagaimana mengelola homestay yang baik. Banyak juga masyarakat yang ingin menjadikan rumahnya sebagai homestay tetapi masih ragu karena kondisi rumah mereka. Di masyarakat pun beredar opini mengenai keinginan mereka pada bantuan atau sebuah program untuk mengembangkan rumah menjadi homestay secara mandiri. Selain usaha homestay dan jasa pemandu wisata, usaha pengemasan produk oleh-oleh khas Ciletuh Geopark Ciletuh-Palabuhanratu juga dijalankan oleh masyarakat secara individu maupun melalui komunitas lokal. Misalnya pengembangan usaha produksi roti berbentuk penyu sebagai kudapan yang menjadi ciri khas Pantai Pangumbahan oleh tujuh orang ibu-ibu PKK di Kecamatan Ciracap. Pelatihan pengemasan produk pada masyarakat juga diberikan oleh PAPSi.

Yani (45) adalah salah satu ibu rumah tangga yang mengikuti pembinaan oleh PAPSi. Yani bekerja sehari-hari mengurus rumah sedangkan suaminya menggarap lahan. Sesekali ia menerima jasa memasak untuk hajatan di kampungnya. Ia bergabung dengan PAPSi untuk mengikuti pembinaan dengan alasan ingin mencoba memasak makanan yang dapat dikemas dan dijual. Ia memilih mangga sebagai produk kemasannya.

Produk oleh-oleh khas Ciletuh Geopark Ciletuh-Palabuhanratu ternyata bukan hanya dibuat oleh ibu-ibu PKK dan masyarakat yang mengikuti pelatihan saja. Para pemuda Karang Taruna di Kecamatan Ciracap juga membuat produk kemasan untuk oleh-oleh khas Ciletuh Geopark Ciletuh-Palabuhanratu berupa tembakau. Idah (31) adalah salah satu pemuda yang berinisiatif mengemas tembakau menjadi oleh-oleh khas Geopark. Ia dan teman-temannya mulai mengemas tembakau 'Kebul Jampang' mulai awal tahun 2017 lalu.

\section{Geowisata dan Kemunculan Kelompok Pengelola Wisata}

Dua jenis kelompok pengelola wisata yang 
muncul di kawasan Geopark Ciletuh-Palabuhanratu adalah 1) kelompok berbasis masyarakat yang didirikan oleh pemerintah yang dikelola oleh masyarakat seperti Pokmasi (Kelompok Masyarakat Konservasi), Pokmaswas (Kelompok Masyarakat Pengawas), Balawista (Badan Penyelamat Wisata Tirta) dan Kompepar (Kelompok Penggerak Pariwisata); dan 2) kelompok yang murni dibentuk oleh masyarakat yaitu PAPSi (Paguyuban Alam Pakidulan Sukabumi), Discover Jampang, Palapah (Paguyuban Lahan Parahyangan) dan OffPak (Offroad Pakidulan).

Sebelum Kecamatan Ciemas dan Kecamatan Ciracap dikukuhkan sebagai bagian dari Geopark Ciletuh-Palabuhanratu pada 2015, komunitas-komunitas tersebut semula mempunyai kegiatan masing-masing. Seperti Discover Jampang yang fokus pada kegiatan jelajah alam Pajampangan dan PAPSi yang fokus pada penghijauan. Sejak Ciletuh Geopark Festival 1 diselenggarakan di Kecamatan Ciemas, komunitas-komunitas tersebut dirangkul oleh Badan Pengelola Geopark Ciletuh-Palabuhanratu sebagai mitra dalam pengembangan geopark. Hal ini sebagai salah satu upaya pelibatan masyarakat dalam pengembangan kawasan Geopark Ciletuh-Palabuhanratu.

\section{Kebangkitan Seni Lokal dan Komodifikasi Budaya}

Geopark Ciletuh-Palabuhanratu turut mendorong pelestarian keragaman budaya setempat. Hal itu kemudian juga mendorong warga masyarakat untuk menumbuhkan kembali kesenian lokal di Kecamatan Ciracap dan Kecamatan Ciemas. Sebanyak 15 desa di Kecamatan Ciracap dan Ciemas mempunyai beberapa seni budaya yang masih tersua di masyarakat yang berpotensi untuk dipopulerkan kembali. Upaya untuk revitalisasi sudah dilakukan oleh Palapah.

Salah satu upaya yang dilakukan Palapah adalah revitalisasi Kesenian Cépét dan Kesenian Gondang. Selain revitalisasi dua bentuk kesenian itu, seni eksperimental juga diciptakan oleh Palapah dan tokoh budaya di masyarakat untuk memperkenalkan kawasan Geopark Ciletuh-Palabuhanratu. Beberapa bentuk seni eksperimental adalah tari Liliuran dan tari Suligar. Sejumlah sekolah (SD, SMP dan SMA) di sekitar Kecamatan Ciracap dan Ciemas juga menjadikan beberapa bentuk kesenian menjadi muatan lokal dengan tujuan untuk membangkitkan kembali kesenian lokal.

Kesenian seperti Buncis yang dahulu dikenal sebagai seni buhun (lawas atau tua) dan mempunyai unsur magis pun dipopulerkan kembali. Pemain Buncis kini rata-rata sudah lanjut usia. Kesenian Buncis kini berubah karakteristiknya, tidak lagi sebagai bentuk seni magis tetapi sebagai bentuk seni hiburan biasa yang dipertunjukkan dalam perayaan-perayaan: seperti pernikahan, festival, atau penyambutan tamu kenegaraan. Pemain Buncis muda pun mulai bermunculan seiring dengan adanya upaya revitalisasi. Kesenian lain yang juga direvitalisasi adalah Cépét, Dog-dog dan Gondang.

Kesenian eksperimental seperti Kesenian Liliuran dan Suligar juga muncul sebagai bagian dari keragaman seni budaya di Geopark Ciletuh Palabuhanratu. Seni eksperimental tersebut adalah hasil ekspresi dari tradisi dan keseharian masyarakat yang kemudian dituangkan dalam tarian dan musik. Tari Liliuran terinspirasi dari hubungan kerja timbal balik antara masyarakat di Pajampangan, sedangkan Tari Suligar menggambarkan tentang kehidupan para penderes kelapa di Pajampangan yang tertindas oleh para tengkulak gula kelapa.

Kegiatan pariwisata di Geopark Ciletuh-Palabuhanratu memanfaatkan beberapa ciri khas budaya di Kecamatan Ciemas dan Ciracap sebagai komoditas kegiatan geowisata. Salah satunya adalah penyadap atau penderes kelapa, sebagai salah satu mata pencaharian yang menjadi komoditas dalam kegiatan geowisata di kedua kecamatan tersebut. Pasalnya, proses penyadapan atau menderes kelapa tidak jarang disuguhkan sebagai atraksi wisata bagi 
pengunjung. Tidak hanya proses menderes kelapa, pengolahan nira kelapa sebagai gula juga diperlihatkan pada wisatawan. Meskipun untuk melihat proses penyadapan sampai pengolahan gula tidak dipungut biaya, namun produk gula aren dari hasil proses tersebut menarik sebagai oleh-oleh khas untuk dibawa pulang wisatawan.

Cecep (36), adalah salah satu anggota pendiri Palapah yang sampai saat ini masih ikut serta dalam pendataan kesenian di kawasan Geopark Ciletuh-Palabuhanratu. Ia bercerita bahwa ia khawatir jika para seniman merasa jenuh dengan seni budayanya sendiri. Palapah beserta komunitas lainnya mencari cara agar kesenian khas di Pajampangan dimasukkan dalam pelajaran muatan lokal di Sekolah Dasar hingga Sekolah Menengah Atas dan dilestarikan kembali di masyarakat. Salah satu kesenian yang diajarkan di sekolah yaitu Dog-dog, kesenian ini menjadi salah satu materi muatan lokal di sejumlah sekolah di Kecamatan Ciracap. Cecep juga menjelaskan langkah-langkah revitalisasi seni Gondang. Saat melakukan revitalisasi Gondang, awalnya sangat sulit karena kesenian itu telah tenggelam \pm 30 tahun yang lalu akibat tidak adanya regenerasi seniman kesenian Gondang. Revitalisasi seni Gondang dilakukan dengan cara menyusuri informasi dari sejumlah sesepuh mengenai sejarah kesenian Gondang. Palapah memutuskan membuat versi Gondang yang dicampur dengan kesenian Kliningan dengan durasi lebih pendek. Kesenian hasil revitalisasi ini ditampilkan pertama kali dalam pesta rakyat Ciletuh-Palabuhanratu Geopark Festival 2.

Selain revitalisasi seni, perkembangan seni eksperimental di kawasan geopark Ciletuh-Palabuhanratu juga pesat. Perkembangan seni eksperimental diawali oleh tokoh masyarakat dan komunitas lokal yang berinisiatif menciptakan seni pertunjukan yang khas di masyarakat setempat. Palapah juga mempelopori penciptaan seni eksperimental. Salah satu hasil seni eksperimental oleh Palapah adalah tari Liliuran. Tari Liliuran adalah tari yang ditarikan oleh penari laki-laki dewasa dan anak laki-laki. Tari Liliuran diperkenalkan pada 29 November 2016 dalam Festival Sabilulungan. Cecep bercerita, tari Liliuran terinspirasi dari pakaian sehari-hari orang Pajampangan tempo dulu. Setelah tari tersebut dibuat, Palapah membuat kelompok tari Liliuran dengan versi yang berbeda durasi dan pemain.

Bukan hanya seni yang berbentuk tarian, Batik Pakidulan juga muncul sebagai salah satu bentuk seni yang masuk pada keragaman budaya Geopark Ciletuh-Palabuhanratu yang terdapat di Desa Purwasedar, Kecamatan Ciracap. Warga di Desa Purwasedar mayoritas bermata pencaharian sebagai petani penanam padi, kelapa dan palawija. Nuansa seni tak pernah lagi dijumpai di Desa Purwasedar sejak lama. Kegiatan membatik dimulai oleh Firman (38), seorang seniman yang hobi melukis. Ia menuangkan inspirasinya berupa eksotisme pesona alam dan filosofi kehidupan masyarakat Pakidulan pada kain dan kemudian berkembang menjadi seni batik. Firman kemudian menjalin kemitraan pada 2010 dengan PT Bio Farma dalam bentuk bantuan penyediaan alat, bahan, dan pembinaan manajemen pemasaran untuk memproduksi batik motif Pakidulan. Pada 2012, kemitraan tersebut mengadakan pelatihan membatik dengan menggunakan pewarna alam pada warga di Desa Purwasedar. Pada akhir tahun 2013, jumlah pembatik telah mencapai 20 orang. Tidak berselang lama, awal tahun 2014 seni Batik Pakidulan pun berkembang pesat. Rumah Batik Pakidulan deresmikan pada 2014 sebagai sarana membatik bagi warga Desa Purwasedar oleh Bupati Kab. Sukabumi.

Rumah Batik Pakidulan hingga awal tahun 2017 menampung 35 pembatik (16 ibu rumah tangga dan 19 pemuda-pemudi warga Desa Purwasedar dan sekitarnya). Tempat ini menjadi sumber nafkah baru bagi sebagian warga desa. Di tengah ketidakpastian panen, mereka kini memiliki penghasilan alternatif. Namun, pembatik di Rumah Batik Pakidulan rata-ra- 
ta tidak menjadikan membatik sebagai mata pencaharian utama. Penghasilan yang didapatkan dari membatik beragam dari Rp. 15.000,hingga Rp. 30.000,- per harinya tergantung tingkat keterampilan dan pembatik.

Saat ini, seni Batik Pakidulan memiliki 130 jenis motif. Sebanyak 13 motif diantaranya telah didaftarkan Hak Atas Kekayaan Intelektual (HAKI). Namun, ada motif khas yang sangat populer yaitu motif Curug (air terjun), motif Panenjoan dan motif Jampang Purba.

Budaya secara harfiah adalah suatu cara hidup yang dimiliki bersama oleh sebuah kelompok dan diwariskan dari generasi ke generasi. Sedangkan keragaman budaya Geopark Ciletuh-Palabuhanratu lebih banyak membahas mengenai konstruksi kesenian. Seperti, seni eksperimental dan Batik Pakidulan dibuat belum lama dan belum tumbuh dalam jangka waktu lama di masyarakat. Kesenian yang masih tersua, revitalisasi, seni eksperimental serta Batik Pakidulan yang ditonjolkan sebagai ciri khas keragaman budaya, mengisyaratkan bahwa kebudayaan di Kawasan Geopark Ciletuh Palabuhanratu beradaptasi dengan pengembangan di kawasan itu sendiri.

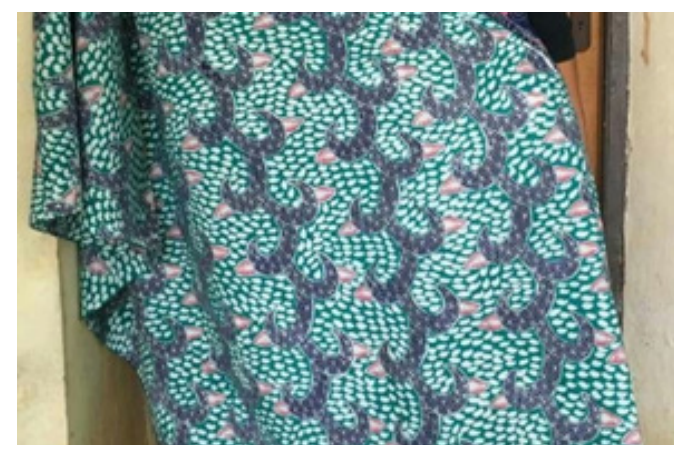

Gambar 2. Motif Batik tulis Panenjoan

(Dokumentasi peneliti, Desember 2017)

\section{Perubahan Pola Interaksi Sosial}

Interaksi antara masyarakat sebagai penyedia fasilitas wisata (host) dan wisatawan (guest) terjalin karena kegiatan geowisata. Interaksi tersebut dapat dilihat dari masyarakat yang ikut serta menjadi pemandu wisata dan pemilik homestay yang bersentuhan langsung dengan wisatawan. Seperti E (55), seorang Ibu yang memiliki homestay. Ia mengaku senang setiap kali kedatangan wisatawan yang menginap di homestay-nya.

E (55) menceritakan bagaimana beragam wisatawan yang menginap di homestay-nya memperlakukannya dan keluarganya. Mulai dari wisatawan yang sangat hangat dan terbuka dengan keluarganya sampai wisatawan yang tidak pernah mengobrol dengannya sama sekali. Ia juga menceritakan bahwa adanya wisatawan di homestay-nya memberikan pengaruh kepada anak-anaknya. Seperti anaknya yang kedua dan ketiga, yang meminta dibelikan gawai/ ponsel pintar seperti milik wisatawan, padahal keluarga mereka hidup seadanya.

Perubahan pola interaksi dapat ditemukan juga di warga masyarakat yang memiliki tanah di kawasan Geopark. Ramainya wisatawan yang mendatangi Geopark Ciletuh Palabuhanratu, membuat sebagian masyarakat yang mempunyai tanah di kawasan ini ramai-ramai menawarkan tanahnya untuk dijual. Salah satunya adalah Alip (59) yang memiliki sebidang tanah di tiga lokasi di Kecamatan Ciemas. Ia menjelaskan bahwa ia menaikkan harga jual tanahnya pada saat Ciletuh-Palabuhanratu Geopark Festival diselenggarakan di pantai Palangpang dan mengetahui bahwa daerahnya adalah bagian dari Geopark Ciletuh Palabuhanratu. Ia memprediksi daerahnya akan ramai sepuluh tahun ke depan, sehingga Alip memutuskan menjual tanahnya untuk modal membuat toko. Hal tersebut membuktikan bahwa keberadaan Geopark Ciletuh Palabuhanratu berdampak pada kenaikan harga jual tanah.

Interaksi yang terjadi antara penyedia fasilitas wisata seperti pemandu wisata dan penyedia homestay (host) dan wisatawan (guest) memperlihatkan bahwa ada perubahan pada pola interaksi di masyarakat. Perubahan pola interaksi juga terlihat pada interaksi sesama warga masyarakat. Perubahan-perubahan tersebut meningkat seiring adanya peningkatan jumlah 
wisatawan yang berkunjung ke Kawasan Geopark Ciletuh Palabuhanratu dalam beberapa tahun terakhir.

\section{Simpulan}

Pengembangan Kawasan Geopark Ciletuh-Palabuhanratu dilakukan sejalan dengan tujuan geopark untuk menggali, menghargai, dan mengambil manfaat dari hubungan erat antara warisan geologi dan segi lainnya mulai dari warisan alam, hingga warisan leluhur yang berupa budaya, dan nilai-nilai di area tersebut. Kecamatan Ciracap dan Kecamatan Ciemas yang lebih dahulu menjadi bagian Kawasan Geopark Ciletuh-Palabuhanratu dibandingkan dengan kecamatan lainnya memiliki potensi untuk pengembangan tersebut.

Dari keseluruhan uraian temuan dan analisis dalam penelitian ini dapat disimpulkan bahwa terdapat perubahan-perubahan sosial-budaya yang dialami masyarakat setempat sebagai akibat dari pengembangan kawasan Geopark Ciletuh-Palabuhanratu. Perubahan dilihat dari keikutsertaan masyarakat dalam kegiatan-kegiatan yang dilaksanakan dalam upaya pengembangan kawasan Geopark Ciletuh-Palabuhanratu. Terjadi perubahan mata pencaharian seiring munculnya peluang usaha baru. Perubahan dalam aspek ekonomi memengaruhi sikap dan pola interaksi dalam keseharian masyarakat. Pola interaksi masyarakat dengan orang luar berubah menjadi interaksi antara warga tuan rumah (host) dan tamu/ wisatawan (guest) ketika kegiatan pariwisata dikelola oleh masyarakat.

Proses komodifikasi dikembangkan dengan oleh-oleh khas Geopark hasil produksi masyarakat, munculnya Batik Pakidulan, serta adanya revitalisasi seni dan seni eksperimental yang kemudian dikomoditisasi seiring dengan berkembangnya kegiatan geowisata di Kawasan Geopark Ciletuh Palabuhanratu. Masyarakat menjadi lebih terbuka dengan adanya diversifikasi mata pencaharian seperti petani yang menjadi pembatik serta ibu rumah tangga yang men- jadi produsen keripik.

Penelitian initerkait dengan perubahan sosial-budaya, pengembangan masyarakat, komodifikasi budaya dalam konteks pengembangan sebuah kawasan wisata Geopark Ciletuh-Palabuhanratu. Penelitian ini belum dapat membangun sebuah analisis tentang akan seperti apa perubahan yang ada saat ini di masa mendatang serta seperti apa model ideal pengembangan masyarakat yang berkelanjutan jika dilihat dari perubahan yang sudah terjadi saat ini. Berbagai konsekuensi seperti dampak dari perubahan-perubahan tersebut belum bisa penulis sajikan di sini, mengingat keterbatasan pengetahuan dan waktu. Penulis melihat bahwa penelitian dengan sudut pandang antropologi berkenaan dengan pengembangan masyarakat dalam sebuah kawasan seperti geopark dapat dipertimbangkan sebagai acuan pengembangan ke depannya.

\section{Daftar Pustaka}

Andriany, S., Rosana, M., dan Hardiyono, A. (2016). Geowisata Geopark Ciletuh: Geotrek Mengelilingi Keindahan Mega Amfiteater Ciletuh (The Magical Of Ciletuh Amphitheater). Bulletin of Scientific Contribution, Volume 14, Nomor 1, April, 7588.

Badan Pengelola Geopark Ciletuh Palabuhanratu. (2015). Keragaman Hayati Geopark Ciletuh Palabuhanratu. Ciletuh Palabuhanratu Geopark: http://ciletuhpalabuhanratugeopark.org/keragaman/keragaman-hayati/

Biantoro, R., dan Ma'rif, S. (2014). Pengaruh Pariwisata terhadap Karakteristik Sosial Ekonomi Masyarakat pada Kawasan Objek Wisata Candi Borobudur Kabupaten Magelang. Jurnal Teknik PWK Volume 3 No 4, 1038-1047.

BPGC. (2017). Jalur Geowisata Geopark Ciletuh Palabuhanratu. Sukabumi: Badan Pengelola Geopark Ciletuh Palabuhanratu.

Chen, A., Lu, Y., dan Ng, Y. C. (2015). The Principles of Geotourism. Springer. 
Cole, S. (2008). Tourism, Culture and Development: Hopes, Dreams and Realities. Toronto: CHANNEL VIEW PUBLICATIONS.

Creswell, J. W. (2016). Research Design: Pendekatan Metode Kualitatif, Kuantitatif dan Campuran (edisi Empat). Yogyakarta: Pustaka Pelajar.

Dipayana, A., dan Sunatra, I. N. (2015). Dampak Pariwisata Terhadap Alih Fungsi Lahan di Desa Tibubeneng, Kecamatan Kuta Utara, Kabupaten Badung (Studi Sosial Budaya). Jurnal Destinasi Pariwisata Vol. 3 No 2, 58-66.

Febriyanto, A., Riawanti, S., dan Gunawan, B. (2017). Mitos Rambut Gimbal: Identitas Budaya dan Komodifikasi di Dataran Tinggi Dieng. UMBARA : Indonesian Journal of Anthropology Volume 2, 1-9.

Ginting, N., dan Sasmita, A. (2018). Developing Tourism Facilities Based on Geotourism in Silalahi Village, Geopark Toba Caldera. IOP Conference Series: Earth and Environmental Science (Vol. 126), 12163.

Gunawan, H., Suryadi, K., dan Malihah, E. (2015). Analisis Perubahan Sosial Budaya Masyarakat Desa Cihideung sebagai Desa Wisata. Jurnal Sosietas, Vol. 5, No. 2, 1-9.

Hardiyono, A., et al. (2015). Potensi Geowisata di Kawasan Teluk Ciletuh, Sukabumi, Jawa Barat. Bulletin of Scientific Contribution Vol 13, No 2, Agustus, 119-127.

Keesing, R. M. (1997). Teori-Teori Tentang Budaya. Jurnal Antropologi Indonesia. No. 52, 4-25.

Keever, P. J., dan Zouros, N. (2005). Geoparks: Celebrating Earth Heritage, Sustaining Local Communities. EPISODES, December, 274-278.

Koentjaraningrat. (1997). Metode-Metode Penelitian Masyarakat. Jakarta: PT. Gramedia Pustaka Utama.

Lauer, R. H. (1993). Perspektif tentang Perubahan Sosial. Jakarta: PT. Rhineka Cipta.

Rosana. (2016). Profil Ciletuh Palabuhanratu. 25 November 2016 г. Geopark Ciletuh Palabuhanratu: http://ciletuhpalabuhanratugeopark.org/profil-ciletuh-palabuhanratu/ \#1469846013413-a2be2a15-e078

Scoones, I. (2015). Sustainable rural livelihoods and rural development. Practical Action Publishing and Winnipeg.

Shepherd, R. J. (2002). Commodification, culture and tourism. Tourist Studies, 183-201.

Soekanto, S. (2012). Sosiologi: Suatu Pengantar. Jakarta: Rajawali Pers.

Wahyudi, H. (2012). Pariwisata, Pengetasan Kemiskinan dan MDGs. Universitas Terbu$k a$ (repository.ut.ac.id), 1-12.

Wood, M. (2002). Ecotourism: Principles, practices and policies for sustainability. UNEP.

Yoety, O. A. (1994). Komersialisasi Seni Budaya dalam Pariwisata. Bandung: Percetakan Angkasa.

Yuliawati, A. K., \& dkk. (2016). Developing Geotourism as Part of Sustainable Development at Ciletuh Sukabumi, West Java, Indonesia. Journal of Enviromental Management and Tourism (Vol. VII, Summer), 57-62.

Zubaedi, D. (2013). Pengembangan Masyarakat: Wacana dan Praktik. Jakarta: Kencana Prenada Media Group. 